\title{
PENYUSUNAN PEMBUKUAN DAN LAPORAN KEUANGAN UNTUK USAHA MIKRO DAN KECIL DI WILAYAH KAMPUNG PULO GEULIS BOGOR
}

\author{
${ }^{1}$ Titi Suhartati, ${ }^{2}$ Herbirowo Nugroho, ${ }^{3}$ Utami Puji Lestari, ${ }^{4}$ Elisabeth Y. Metekohy, \\ ${ }^{5}$ Lia Ekowati, ${ }^{6}$ Yusep Friya Purwa Setya \\ ${ }^{123456}$ Politeknik Negeri Jakarta \\ Jl. Prof.Dr. Siwabessy-Kampus Universitas Indonesia, Depok 16425 \\ 1iti.suhartati@akuntansi.pnj.ac.id
}

\begin{abstract}
Micro and small businesses are growing rapidly in the community but have weaknesses in the process of recording, accounting and compiling financial reports in accordance with applicable standards. The purpose of this activity is to provide training and mentoring on bookkeeping and compilation of simple financial reports to the micro and small business in the Kampung Pulo Geulis area, Babakan Pasar, Bogor as the activity partner. Community service activities seek to improve the ability of micro and small business managers and expected to improve the economic quality of the community in the area which has processed of developing into a tourism area in Central Bogor. The method of implementing activities are training and assisting of the activity of the participants which can provide optimal results to improve the community's economy, especially for those who need additional funds for their business. The selected samples are 25 micro and small businesses as the participants. The training was in the form of lectures and practicums accompanied by consulting and assisting in preparing a simple of financial report. The results of this activity will be in the form of simple bookkeeping guidelines and preparation of financial statements for micro and small businesses that can be understood by the participants.
\end{abstract}

Keywords: bookkeeping, reporting, micro and small business

\begin{abstract}
Abstrak
Usaha mikro dan kecil sangat berkembang pesat di masyarakat tetapi memiliki kelemahan dalam proses pencatatan, pembukuan dan penyusunan laporan keuangan sesuai standar yang berlaku. Tujuan kegiatan ini adalah untuk memberikan pelatihan dan pendampingan atas pembukuan dan penyusunan laporan keuangan sederhana kepada pengelola usaha mikro dan kecil yang sangat beragam di wilayah kampong Pulo Geulis, Babakan Pasar, Bogor sebagai mitra kegiatan. Kegiatan pengabdian masyarakat berupaya meningkatkan kemampuan pengelola usaha mikro dan kecil dan diharapkan berdampak pada peningkatan kualitas ekonomi masyarakat di wilayah mitra kegiatan yang dalam proses pengembangan menjadi daerah Wisata di wilayah Bogor Tengah. Metode pelaksanaan kegiatan dalam bentuk pelatihan dan pendampingan kepada mitra kegiatan sehingga dapat memberikan hasil optimal untuk peningkatan ekonomi masyarakat, terutama bagi yang membutuhkan tambahan dana bagi usahanya. Terpilih sampel sebanyak 25 usaha mikro dan kecil sebagai mitra kegiatan. Pelatihan tersebut dalam bentuk ceramah dan praktikum disertai dengan konsultasi dan pendampingan. Hasil dari kegiatan ini berupa panduan pembukuan dan penyusunan laporan keuangan usaha mikro dan kecil yang sederhana yang dapat dipahami oleh mitra kegiatan.
\end{abstract}

Kata Kunci: Pembukuan, Laporan, Keuangan, Usaha Mikro dan Kecil 


\section{Pendahuluan}

Usaha Mikro, Kecil dan Menengah (UMKM) di berbagai negara termasuk Indonesia merupakan salah satu penggerak perekonomian rakyat yang tangguh. Hal ini karena kebanyakan para pengusaha kecil dan menengah berasal dari industri keluarga atau rumahan. Usaha mikro adalah usaha yang sangat bertahan dan berdampak signifikan terhadap kondisi ekonomi Indonesia secara global, tetapi tidak berdampak langsung terhadap para pelaku usaha mikro.

Semakin berkembangnya usaha, menuntut para pelaku usaha mikro untuk berhubungan dengan pihak eksternal perusahaan. Misalnya untuk meningkatkan pendanaan, usaha mikro akan berhubungan dengan pihak bank/ lembaga keuangan lainnya. Pihak bank/ lembaga keuangan tersebut biasanya mensyaratkan laporan keuangan untuk menilai kelayakan kredit dari usaha tersebut. Karena pada umumnya mereka tidak mempunyai keterampilan khusus dan sangat kekurangan modal kerja. Oleh sebab itu, produktivitas dan pendapatan mereka cenderung lebih rendah daripada kegiatan-kegiatan bisnis lainnya (Hapsari, Andari, Hasanah, 2017).

Usaha mikro dan kecil (UMK) yang berada di Kampung Pulo Geulis, Babakan Pasar merupakan usaha yang tumbuh secara tradisional dan merupakan usaha keluarga yang turun temurun. Keterbatasan kualitas SDM usaha kecil baik dari segi pendidikan formal maupun pengetahuan dan keterampilannya sangat berpengaruh terhadap manajemen pengelolaan usahanya, sehingga usaha tersebut sulit untuk berkembang dengan optimal. Disamping itu dengan keterbatasan kualitas SDM-nya, unit usaha tersebut relatif sulit untuk mengadopsi perkembangan teknologi baru untuk meningkatkan daya saing produk yang dihasilkannya.

Masalah-masalah yang dihadapi usaha mikro utamanya adalah dalam hal pencatatan keuangan. Usaha ini cenderung mengabaikan pentingnya melakukan pencatatan keuangan. Secara finansial tercampur, mereka tidak memisahkan antara kebutuhan modal kerja dengan kebutuhan rumah tangga. Tidak teridentifikasi berapa laba riil yang didapatkan dari penjualan untuk menopang modal dan menopang kebutuhan rumah tangga. Tidak jarang problem yang dialami oleh para pelaku usaha mikro ini adalah selalu seputar kekurangan modal.

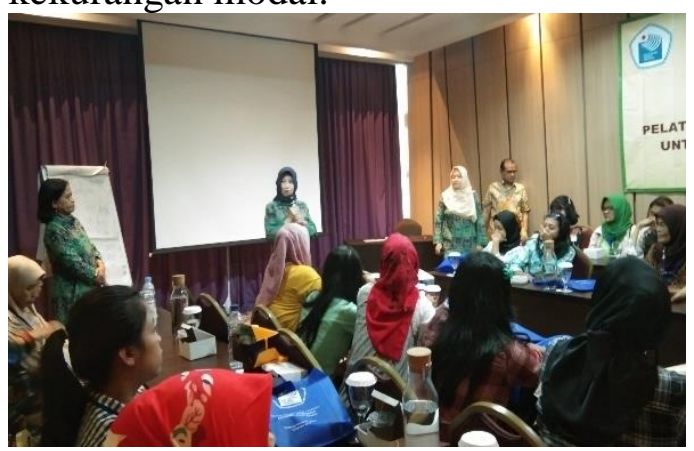

Gambar 1. Pembukaan Pengabdian

\section{Metode Pengabdian}

Metode yang digunakan dalam pelaksanaan program Iptek Bagi Masyarakat Berbasis Program Studi terkait dengan tahapan atau langkahlangkah dalam menyelesaikan solusi dari permasalahan mitra kegiatan.

Metode ini dilakukan dengan memberikan pelatihan dan pendampingan dalam penyusunan pembukuan dan laporan keuangan sederhana untuk usaha mikro dan kecil. Metode pelaksanaan: Memberikan pelatihan dan pendampingan untuk penyusunan pembukuan dan laporan keuangan sederhana untuk UMKM sesuai dengan standar akuntansi yang berlaku (SAK-ETAP). Sehingga para pengusaha dapat mengetahui hasil usaha selama ini dan hasil dari pembukuan 
dapat ditingkatkan menjadi laporan keuangan.

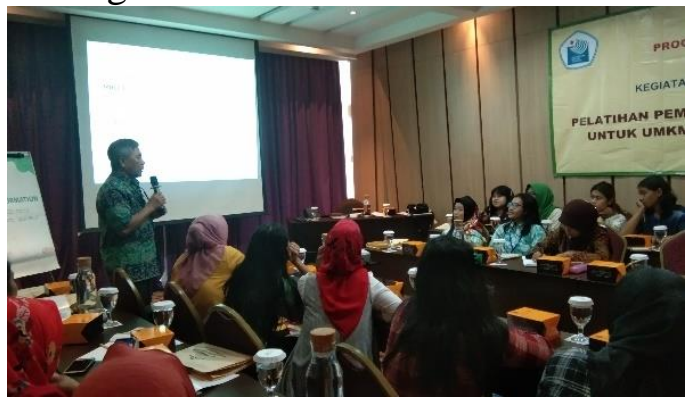

Gambar 2. Pelatihan UMK Kampung Pulo Geulis

Laporan keuangan yang sesuai standar yang berlaku dapat digunakan sebagai salah satu kriteria atau persyaratan bila akan melakukan pinjaman dana kepada pihak penyedia jasa keuangan atau bank

\section{Hasil dan Pembahasan}

Kegiatan pengabdian kepada masyarakat telah dilaksanakan pada tanggal 1 September 2019, dengan dihadiri oleh 25 peserta dari warga setempat dari Kampung Pulo Geulis Bogor yang merupakan komunitas pengusaha rumahan. Kegiatan ini juga dihadiri dan dibuka oleh pejabat Desa dan RW setempat.

Kegiatan dilaksanakan mengambil lokasi di Hotel 101- Suryakencana Bogor yang sejak awal memberikan dukungan untuk kegiatan ini. Kegiatan dimulai dengan beberapa sambutan dari Kepala P3M dan Ketua Jurusan Akuntansi Politeknik Negeri Jakarta serta dilanjutkan oleh Ketua RW Kampung Pulo Geulis. Kegiatan telah disusun dalam jadwal acara dengan menyajikan beberapa materi melalui proses penyampaian oleh narasumber dari Program Studi Akuntansi Politeknik Negeri Jakarta.

Materi yang disampaikan, antara lain: pengetahuan mengenai transaksi keuangan dan pencatatan transaksi keuangan sederhana. Materi tersebut dikemas dalam beberapa contoh yang sederhana sehingga lebih mudah dipahami para peserta. Selama proses ini para peserta diberikan bantuan berupa seminar kit, kalkulator dan buku khusus untuk mencatat transaksi keuangan. Hal ini ditujukan untuk membantu pengerjaan praktik kasus dan akan lebih memudahkan pada saat dilakukan pendampingan.

Selanjutnya para peserta diberikan contoh kasus transaksi keuangan sederhana didampingi oleh para nara sumber, dosen dan mahasiswa yang hadir. Kemudian dilanjutkan dengan tanya jawab atas materi yang disajikan. Luaran kegiatan ini diharapkan agar peserta memahami proses pencatatan sederhana dan dapat menyajikan sendiri melalui laporan transaksi keuangan sederhana. Tujuannya untuk mempermudah proses bisnis yang selama sudah dilakukan tetapi belum memiliki pencatatan yang jelas. Kegiatan selanjutnya, yaitu dilakukan pendampingan oleh Tim dengan dukungan dari beberapa mahasiswa terkait dengan pelaksanaan proses pencatatan sederhana dan penyusunan laporan keuangan sederhana sehingga hasilnya diharapkan dapat bermanfaat bagi para pengusana mikro dan kecil untuk pengelolaan modal mendatang. Pelaksanaan kegiatan ini dipublikasikan dalam media online, antara lain Harian Depok Terkini dan Harian Pelita.

\section{Kesimpulan}

Kegiatan pengadian kepada masyarakat dari Program Studi Akuntansi Keuangan Terapan Politeknik Negeri Jakarta telah terlaksana dengan baik berkat dukungan semua pihak yang terkait. Telah disampaikan materi terkait pencatatan transaksi keuangan dan laporan sederhana oleh para narasumber dan diberikan latihan kasus yang sesuai dengan transaksi yang terjadi pada industri rumahan (UMK). Kegiatan ini diharapkan berlanjut dengan kegiatan 
yang terkait pencatatan transaksi yang mendukung perkembangan usaha para pengusaha mikro dan kecil di wilayah Kampung Pulo Geulis, seperti pencatatan pajak dan pengelolaan persediaan. Hal ini membutuhkan dukungan dari aparat, para praktisi, masyarakat dan kelurahan/RT/RW setempat.

\section{Ucapan Terima Kasih}

Rasa terima kasih diucapkan kepada seluruh pihak yang mendukung terlaksananya Kegiatan Pengadian kepada Masyarakat dari Program Studi Akuntansi Keuangan Terapan Jurusan Akuntansi Politeknik Negeri Jakarta (PNJ). Kepada Pimpinan, Ketua Jurusan Akuntansi dan Unit P3M PNJ yang telah memberikan kesempatan dan dukungan dana (DIPA PNJ tahun 2019) dalam pelaksanaan kegiatan ini. Kepada seluruh Tim Panitia, Aparat Kelurahan/RT/RW dan masyarakat wilayah Kampung Pulo Geulis-Bogor yang telah mendukung dan berpartisipasi dalam kegiatan ini.

\section{Daftar Pustaka}

Anggraeni, Hubeis, Musa. 2012. Penerapan Sistem Akuntansi Sederhana Pada UKM Cireng Cageur Group Bogor. Institut Pertanian Bogor

Hapsari, Andari, Hasanah. 2017. Model Pembukuan Sederhana Bagi Usaha Mikro Di Kecamatan Kramatwatu Kabupaten Serang. Jurnal Akuntansi. Vol 4. No. 2. Juli. Hal. 36-47.

Hermon dan Elisabeth, 2016. Penyusunan Laporan Keuangan Untuk UKM Berbasis SAK ETAP. Universitas Kristen Satya Wacana. Salatiga.

Ikatan Akuntan Indonesia (IAI). 2009. Standar Akuntansi Keuangan Entitas Tanpa Akuntabilitas Publik (SAKETAP), Jakarta
Keputusan Menteri Keuangan No. 40/KMK.06/2003 tentang Pendanaan Kredit Usaha Mikro dan Kecil.

Krisdiartiwi, Nanik, 2008. Pembukuan Sederhana untuk UKM, Media Pressindo, Yogyakarta.

Undang-Undang Republik Indonesia Nomor 20 Tahun 2008 tentang Usaha Mikro, Kecil dan Menengah. 